\title{
Problems of International Relations
}

\section{Rafig Aliyev Huseyn}

Art. prepodatel kafedary, Political Science and Sociology, Ganja otdpeleniya Gosunivaersiteta, Azerbaijan Volqa_5@mail.ru

\begin{abstract}
This article provides the problem is that the stability of democracy in any country is based in the first place on the faith of citizens in democratic values, the pursuit of personal freedom and respect for the freedom of others, multikulturalism, tolerance for people who do not share their political views, personal enterprise and initiative, etc. It should be recognized that the most important of these conditions is the presence in society of political culture of a democratic type of desire formation of a single world space which lead humanity towards progress and prosperity, the development of modern international relations globalization, defining as the formation of a single world space, not only in the political sphere, but also in the field of economy, science, and so, for what purpose and requires a long period of time during which the society is just about going on the formation of the above-mentioned qualities.
\end{abstract}

Keywords: totalitarianism theory of democracy, the Commonwealth of Independent States, international relations, foreign policy, political stability, globalization.

\section{INTRODUCTION}

The study of the problems of international relations has a special place in political science. This is primarily due to the fact that the concept of "international relations" assumes an exit policy issues to a new - international, global level. If the formation of the domestic politics and domestic public and political structures existing in a particular country's political regime is loose enough in the ongoing activities, the steps taken in the international arena, he is forced to reckon with the position of other countries of the world community as a whole.

In addition, the meaning of «international relations» is not confined to only one political factors. In addition to the political component of international relations are also formed economic and cultural relations, etc. For this reason, in the field of international relations, political science comes into close contact with other social disciplines involved in the system of modern international relations - international law, the world economy.

\section{MOVES INTERPRETATION OF STUDY AND DISCUSSION}

Moves study and discussion of the results First, you need to define the very concept of international relations. According to the author, sufficiently accurate and complete is the following interpretation. International relations can be defined as "a system of political, economic, international relations and interactions ... arising between the subjects of the world community."

Let us now discuss in more detail in consideration of what is meant by the term «subject of the world community.» Traditionally, the main «actor» of the system of international relations is the state. This set of steps being taken 
by various States on the world stage, to form international relations as such. These steps are called foreign policy. Thus, the foundation of international relations has traditionally been a set of foreign policy lines carried out by different countries of the world.

In turn, the state's foreign policy was determined by the so-called national interests, which «represents the awareness of and reflected in the activities of its leaders of indigenous needs of the state».17 These requirements, in turn, «are expressed in national security and the conditions for the survival and development of society«.

Here, however, it is necessary to make a significant reservation.

The practice of the system of international relations shows that quite often, especially in the event of a crisis can not work out a common interpretation of national interest on a national scale. Various social groups, power groups, according to different interpretations of the concept of national interest. A striking example of this are the events associated with the emergence and development of the so-called Cuban Missile Crisis in 1962 During the crisis, there was a real threat of nuclear war between the Soviet Union and the United States. She averted thanks in part to the positions occupied by the leaders of the two states - NS Khrushchev and John F. Kennedy. At the same time, however, the course of events in the USSR and the United States seriously affected power groups, with their position in respect of a crisis, mismatched with the view of the leader of the state. For example, in the US there was a group of top military leaders and influential members of the ruling circles, insist on applying nuclear strike on the Soviet Union and put serious pressure on President John F. Kennedy. Only thanks to the hardness shown by John F. Kennedy managed to prevent such a scenario.

The position of the state as the main element of the formation of the system of international relations is largely changed in the XX century. There are a number of factors unrelated directly to the concept of the state, but providing a major impact on the formation of the system of international relations. Among them - a nuclear weapon, the formation of a single global information and economic space, etc. A special role in the contemporary world scene is played by various non-governmental organizations, in the first place - the United Nations (UN).

Thus, contemporary international relations form a set of two components - the state (ie, the aggregate foreign policy efforts around the world) and private (a combination of factors that influence the development of international relations but unrelated directly to the concept of the state).

We now turn to the consideration of the main problems of international relations - the problem of its stability, the problem of preserving peace and preventing war between the states - participants of the system of international relations. As to the theoretical and practical level in the solution of this problem, there are two basic, basic approaches.

The basis of the first approach is the so-called principle of «balance of power». It can be defined as «a particular historical relationship of the specific weight and influence in the system of states, and first of all the great powers».19 In other words, the stability of the system of international relations, the preservation of peace or the beginning of the war entirely dependent on the military and economic potential, focused in the hands of the so-called great powers - of the world's most advanced military and economic terms.

Under the concept of «balance of power», the greater the military and economic potential is concentrated in the hands of his great powers, the more likely the preservation of peace. The main deterrent, to prevent the outbreak of war, the fear of mutual destruction. Leaders of the world's great powers, and led by two powers 
opposing military and political blocs were aware that in the case of an open military confrontation will not be able to win a victory neither one nor the other side.

It can not be admitted that the concept of «balance of power» contained a certain grain of truth. For example, at the end of the Second World War, the world has developed so-called «bipolar model» device in the system of international relations based on the confrontation of the two superpowers - the USSR and the USA and they headed military-political blocs - the Warsaw Treaty Organization (WTO) and the North Atlantic Alliance (NATO), respectively. The presence of the opposing sides of the huge military capabilities, especially nuclear weapons, has led to the realization of the leaders of both the USSR and the US inability to open military conflict which would inevitably lead to the destruction of not only the opposing sides, but of humanity as a whole. It is because of the fear of mutual destruction, understanding the impossibility of winning a nuclear war either party, managed to avoid the beginning of World War III.

At the same time, however, the concept of «balance of power» has a significant drawback, which is best manifested itself in the XX century - in connection with the advent of weapons of mass destruction. Its essence lies in the fact that the opposition of the great states united in the military-political alliances lead to an arms race, which sooner or later becomes uncontrolled leaders of the character. The increase in military spending by one party is perceived as a challenge to the other, and leads to a reciprocal increase in military spending. In turn, the first of the opposing party accepts it as a challenge and again increases military spending, etc.

Thus, during the so-called «Cold War» confrontation between the USSR and the United States, the total nuclear weapons parties exceeded all reasonable limits. Togo's nuclear potential, which gained the Soviet Union and the United States would be sufficient to repeatedly destroy all mankind. Such an avalanche coming out of the control of the accumulation of weapons, especially nuclear, carried with it a number of problems.

First, the problem of unauthorized nuclear war that occurred as a result of technical failure. The more was gained nuclear capability, the higher the probability of this. Here there was a kind of principle of the transformation of quantity into quality.Secondly, the increase in nuclear potentials led to the expansion of the circle of persons having access to nuclear weapons. Although formally the right to order the use of nuclear weapons belonged only to the leaders of the leading states in practice in making decisions related to the use of nuclear weapons was a fairly wide range of high-ranking politicians and military. This provision has already been illustrated by the example of the Cuban missile crisis in 1962.

Third, the development of nuclear technology has led to a kind of «spreading» of nuclear weapons, that is, his appearance in a number of countries. The main danger was that the number of these countries may well get to the unstable state, or simply totalitarian political regimes (such as North Korea or Pakistan). Level of responsibility for the actions taken at the state of this type is quite low, and they can use nuclear weapons as a method of solving a political problem.

Particularly acute, this problem today - the beginning of the XXI century. This is due to the appearance on the world stage of a fundamentally new political factor - global terrorism, it has a well-organized international terrorist organization which has set itself the task of carrying out terrorist acts in the largest countries of the world with the aim of destabilizing the situation on a global scale. It is not difficult to understand that getting into the hands of terrorists nuclear weapons threatens to tragic consequences for all mankind. 
Another approach to solving the above problem - that is, maintaining the stability of the international system, preventing wars and armed conflicts that threaten to lead to the beginning of World War III can be defined as a supranational approach. Its essence is to create a kind of non-state and supra-state organization, which on a global scale would monitor the situation in the world is produced to some kind of «rules of the game» in the international system, obligatory for all states of the world and would monitor their implementation.

The first attempt to realize this idea in practice, was made at the end of the First World War. In 1919 he established the so-called League of Nations - an international organization of a new type, whose main task was to prevent another world war. However, the League of Nations was unable to solve the problem - to prevent another world war. Start of World War II meant the collapse automatically as the League of Nations and the policy pursued by it.

After the war was a new attempt to create an international body that would not allow the start of World War III. This body became established in 1946 by the United Nations (UN), which exists to this day. The main instrument to prevent potential wars and conflicts cease already begun at the disposal of the United Nations, the so-called system of sanctions. The essence of the system of sanctions is that in relation to a State recognized by the international community as an aggressor, uses a variety of punitive measures (economic, political, military).

The successes of the UN in maintaining peace proved to be more significant than the League of Nations. Largely thanks to the United Nations humanity managed to avoid the beginning of World War III, to prevent the occurrence of many local conflicts.

At the same time, however, it should be said that the effectiveness of the United Nations in maintaining peace and avoiding wars reduced the following circumstance. Sanctions against the state - aggressor from the UN were effective only in the case when it comes to normal, «ordinary» state. In that case, if the state belonged to the so-called «Great Powers» (in the first place - the Soviet Union and the United States) applied the UN sanctions were either formal or not applied. In the second half of the XX century, humanity has not just become a witness gross violations of international law by both the Soviet Union and the United States. As an example, the suppression of anti-communist Soviet appearances in Hungary in 1956 and Czechoslovakia in 1968, the US aggression in Vietnam in the 60s - 70s. etc.

Particularly acute problem of the effectiveness of the United Nations stood in the 90-ies of XX century - after the collapse of the Soviet Union and its disappearance from the political map of the world as opposed to the US superpower. The United States in the early XXI century have become the only superpower. As a result, the previously existed so-called bi-polar or bi-polar system of international relations based on confrontation between the Soviet Union and the United States turned into a single-pole or unipolar system in which the United States belongs, in fact global hegemony.

During the 90 -ies of the XX century and the beginning of XX century the United States was openly aggressive policy, ignoring the norms of international law and world opinion. The most striking examples - the US aggression in Yugoslavia and Iraq. In this and in another case, the UN was unable to influence the United States, to limit their aggressive ambitions. In this regard, the conclusion seems justified to reduce the value of the UN as an instrument of peace and prevent war.Thus, both the above-mentioned principle of maintaining a balance in the international system - the principle of «balance of power» and the principle of establishing a 
global international organization which does not allow the violation of stability in the international system has serious shortcomings. In this connection we can probably be concluded that the optimum combination of the aforementioned principles.

On the one hand, it does not lose its significance the principle of «balance of power». It could not be more relevant today is the creation of a counterweight to the United States, the new center of power, which could oppose the United States on an equal footing, and thereby balance the system of international relations. This would make a difference in the world more stable and predictable, would reduce US foreign policy ambitions. Many of today's politicians in the form of such centers of power, balancing the monopoly position of the United States, see the State of the united Europe, Russia, China, as well as various combinations of the above states.

On the other hand, an important task facing the international community is to enhance the prestige and importance of the UN as an instrument of peace and stability. Reducing the efficiency and effectiveness of the UN in the late XX - early XXI centuries does not mean its complete disappearance from the political scene. On the contrary, in the modern situation in the sphere of international relations and the importance of the role of the UN as well as other international organizations is very high.

We now consider the features of the system of international relations late XX - early XXI centuries. At the present stage of development of international relations have acquired a number of new components, new qualities. Let us dwell on them in greater detail.

Firstly, the most important factor of modern international relations is the problem of global terrorism. World terrorism is a fundamentally new component in the system of international relations. Landmark date was September 11, 2001. It can be argued that the events of the day - a large-scale terrorist attack on the United States transferred the international relations to a qualitatively new stage of development. In fact, the United States has declared war on the part of international terrorism. Never before has any country in the world is being attacked and do not have a state of war with any organization. Previously, all the wars, armed conflicts occurred and were fought between states, not between the state and certain non-state actors. Subsequently, this kind of attack from international terrorism were subjected to other nations of the world, including Russia. It therefore could not be more relevant today is the problem of creating a unified international organization, anti-terrorist coalition, whose task is precisely to fight against global terrorism. Another important factor in the development of modern international relations challenges of globalization. Globalization can be defined as the formation of a single world space, not only in the political sphere, but also in the field of economy, science, etc. The emergence of the phenomenon of globalization was primarily due to the weakening at the end of XX-beginning of XXI centuries. the state's position as a major actor in international relations, the rapid development of the economy, has stepped beyond the state borders, information technology related world as a whole.

\section{CONCLUSIONS}

The development of international relations in the modern conditions of life requires the improvement of the economic situation slozhivschieysya in the CIS and other countries, achievement in political stability, availability of public political culture of a democratic type of desire formation of a single world space which will lead humanity to progress and prosperity, the development of modern international relations in conditions of globalization the problem of defining as the formation of a single world space, not only in politics but also in economics, science, etc. 


\section{REFERENCES}

[1] R.G Aliev "Development between. The ratio of the leading scientific societies of the CIS countries in the conditions of market economy. Reflex reading university students pp. 17-24, edition of "Vector" Baku-2011

[2] Aaron R. democracy and totalitarianism. M., 1993.

[3] J. Beshler Democracy: an analytical essay. M., 1994

[4] Krivoguz IM Political science. (Textbook for high schools), M., 1999

[5] Kleimenova NE Sidorov Yu Versailles - Washington system of international relations: problems of formation and development. M., 1995. S. 7

[6] Mukhaev RT Politics. (Textbook for high schools), Moscow, 2003.

[7] LA Nudnenko The theory of democracy. M., 2001.

[8] VP Pugachev Solovyov AI Introduction to political science. M., 2002.

[9] Salmin AI Modern democracy: Essays formation. M. 1997. 10. Totalitarianism in Europe of XX century: the history of ideologies, movements and regimes, and to overcome them. M., 1996.

Citation: Rafig Aliyev Huseyn, "Problems of International Relations", American Research Journal of Humanities and Social Sciences, Volume 2 2016; pp:1-6

Copyright (C) 2016 Rafig Aliyev Huseyn, This is an open access article distributed under the Creative Commons Attribution License, which permits unrestricted use, distribution, and reproduction in any medium, provided the original work is properly cited. 